\title{
Analisis Pengaruh Parameter Operasional Terhadap Perilaku Belok dan Stabilitas Pada Panser Anoa 6X6 APC
}

\author{
Sanditra Muda Yusviva dan I Nyoman Sutantra \\ Departemen Teknik Mesin, Fakultas Teknologi Industri, Institut Teknologi Sepuluh Nopember (ITS) \\ e-mail: tantra@me.its.ac.id
}

\begin{abstract}
Abstrak-Dalam menjaga keamanan dan pertahanan NKRI, lembaga-lembaga seperti TNI dan POLRI memerlukan dukungan kelengkapan-kelengkapan yang optimal, baik kelengkapan diri, persenjataan, dan kendaraan khusus militer. Panser Anoa 6x6 APC merupakan kendaraan khusus yang didesain sebagai kendaraan support dalam medan pertempuran. Keberhasilan Panser Anoa 6x6 APC dalam operasi-operasi militer harus didukung dengan performa handling dan stabilitas yang mumpuni. Untuk itu, perlu dilakukan sebuah penelitian untuk mengetahui pengaruh beberapa variasi parameter operasional terhadap perilaku belok kendaraan sebagai acuan bagi para personel militer dan engineer untuk mengetahui karakter handling dari Panser Anoa 6x6 APC yang merupakan khusus dengan 6 roda (six-wheeled vehicle). Pada penelitian penelitian ini, penulis akan melakukan tiga metode analisis, yaitu analisis slip, skid, dan guling dengan beberapa variasi parameter opersional yaitu kecepatan berkendara, steering angle, dan kondisi permukaan medan. Setelah dilakukan penelitian, didapatkan bahwa kondisi belok paling baik pada Panser Anoa 6x6 APC adalah ketika kendaraan berbelok pada kecepatan $60 \mathrm{Km} / \mathrm{Jam}$ dengan sudut belok $12^{\circ}$ di permukaan jalan tanah, dimana kendaraan mengalami kondisi understeer yang paling sedikit dan koefisien understeer yang bernilai positif terkecil yaitu 0,9265 . Sesuai dengan analisis slip, dan indeks $K_{U S}$, Panser Anoa 6x6 APC memiliki karakter handling yang bersifat understeer, dimana nilai sudut slip depan selalu lebih besar dari sudut slip belakang dan nilai indeks $K_{U S}$ selalu bernilai positif pada tiap rentang kecepatan dan sudut belok yang digunakan pada penelitian. Semakin besar sudut belok yang diberikan maka kecepatan skid dan guling kendaraan akan semakin menurun, dimana berdasarkan analisis skid dapat disimpulkan bahwa Panser Anoa 6x6 APC memiliki kecenderungan untuk sedikit oversteer karena kecepatan skid depan yang nilainya sedikit lebih tinggi daripada kecepatan skid belakang. Demikian halnya dengan analisis guling dimana dapat disimpulkan bahwa Panser Anoa 6x6 APC memiliki kecenderungan untuk sedikit oversteer karena batas kecepatan guling roda depan yang nilainya sedikit lebih tinggi daripada batas kecepatan guling roda belakang. Terakhir, didapat bahwa semakin besar sudut belok dan kecepatan yang diberikan maka besarnya sudut guling yang terjadi akan semakin meningkat. Pada kecepatan $40 \mathrm{Km} / \mathrm{jam}$, sudut guling depan yang terjadi adalah $6,093^{\circ}$ untuk sudut belok $8^{\circ}, 7,605^{\circ}$ untuk sudut belok $10^{\circ}$, dan $9,109^{\circ}$ untuk sudut belok $23,44^{\circ}$.
\end{abstract}

Kata Kunci-Guling, Oversteer, Performa handling, Six-wheeled vehicle, Skid, Slip, Understeer.

\section{PENDAHULUAN}

$\mathrm{P}$ ERTAHANAN dan keamanan suatu negara merupakan aspek penting yang harus berdiri demi tegaknya kedaulatan suatu negara, dimana kedaulatan negara yang utuh menunjukkan bahwa negara tersebut memiliki kedudukan yang sama dengan negara lain. Dalam melaksanakan tugas-tugasnya, baik POLRI dan TNI dibekali dengan alat-alat kelengkapan baik berupa kelengkapan diri, kelengkapan persenjataan personel, dan alat utama sistem senjata (alutsista).

Alutsista yang dimiliki oleh angkatan bersenjata di Indonesia terdiri dari beragam jenis pada 3 matra, darat, laut dan udara, baik berupa alutsista yang bersifat ofensif maupun suportif. Salah satu alutsista yang layak mendapat perhatian khusus adalah kendaraan lapis baja Panser Anoa 6x6 APC.

Sebagai pengangkut personel lapis baja, Panser Anoa 6x6 APC harus mampu menjelajah dengan baik di medan aspal maupun medan off-road tanpa mengorbankan kenyamanan maupun keselamatan personel yang diangkut. Untuk itu, kapabilitas bermanuver, stabilitas, dan pengendalian yang baik pada medan aspal maupun medan off-road menjadi kunci utama dalam keberhasilan misi yang dilaksanakan. Sehingga pada penelitian ini akan dilakukan analisis perilaku, stabilitas, dan kapabilitas bermanuver dari Panser Anoa 6x6 APC sebagai bahan pertimbangan dalam pengoperasian maupun pengembangan kendaraan tempur ini selanjutnya.

\section{URAIAN PENELITIAN}

\section{A. Penelitian Terdahulu}

Analisis terhadap dinamika berbelok kendaraan dengan 6 roda telah dilakukan sebelumnya oleh K. Huh, J. Kim, dan J. Hong pada tahun 1999 [1], dimana analisis dilakukan dengan memodelkan kendaraan kedalam bentuk matematis untuk kemudian dilakukan simulasi dengan bantuan komputer. Kendaraan yang dipelajari dimodelkan kedalam bentuk sistem matematis 18 derajat kebebasan (18 DOF) dimana model tersebut terdiri dari 12 DOF sistem dinamika kendaraan nonlinear, 6 DOF dinamika roda, model ban dan efek kinematik. Model matematis tersebut dianalisa dalam MATLAB/SIMULINK untuk mendapatkan parameterparameter seperti lateral acceleration, lane-change trajectory, sudut stir, dan sideslip angle. Analisa ini dilakukan dengan 
menggunakan variasi terhadap 5 steering mode yang berbeda. Jenis-jenis steering mode yang digunakan dalam simulasi digambarkan pada gambar 1 berikut.

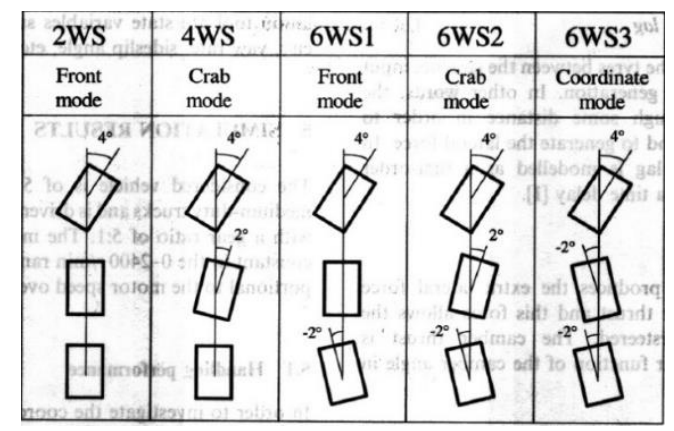

Gambar 1. Steering Modes yang digunakan dalam pengujian [1]

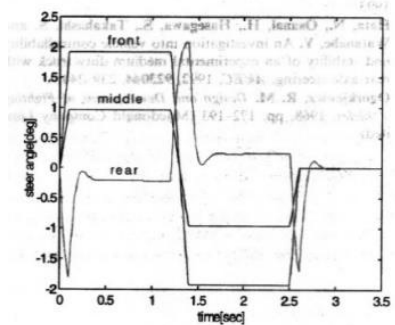

(a)

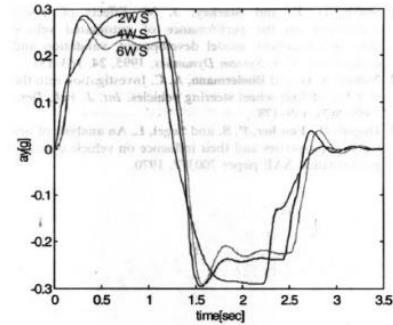

(c)

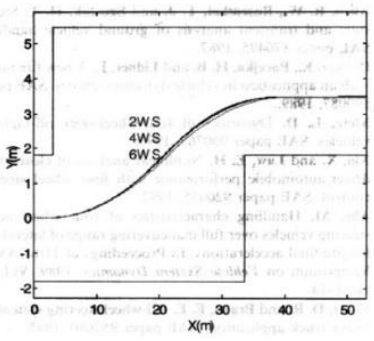

(h)

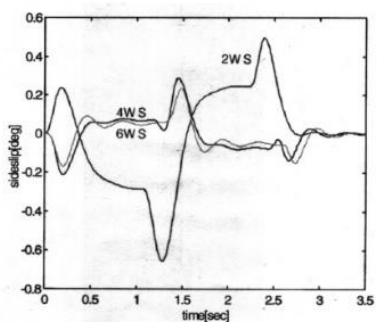

(d)
Gambar 2. Hasil simulasi yang dilakukan; (a) Grafik sudut stir yang digunakan tiap sumbu roda untuk mode 6WS, (b) Grafik lane change trajectory, simpangan lateral terhadap jarak tempuh longitudinal, (c) Grafik lateral acceleration, (d) Grafik sideslip angle [1]

Hasil yang didapatkan menunjukkan bahwa gerakan belok roda tengah tidak dapat diabaikan seutuhnya dan mempengaruhi dinamika kendaraan yang diuji. Tiap-tiap steering mode (6WS) memiliki karakteristik pengendalian yang berbeda-beda, dimana kendaraan dengan six-wheel steering memiliki gain yang lebih besar pada lateral acceleration dan yaw rate dibanding dengan mode $2 \mathrm{WS}$ dan $4 \mathrm{WS}$. Dilakukan juga simulasi performa perpindahan lajur secara zig-zag (lane change maneuver) yang dievaluasi dalam sumbu $\mathrm{x}$ dan $\mathrm{y}$, seperti yang dapat dilihat pada gambar (2) berikut.

\section{B. Perilaku Berbelok Kendaraan}

Terdapat 4 jenis perilaku berbelok yang dapat terjadi pada sebuah kendaraan, yaitu perilaku belok ideal (Ackermann), perilaku belok netral, perilaku understeer, dan perilaku oversteer [2]. Tiap-tiap jenis perilaku berbelok dibedakan berdasarkan sudut slip yang terjadi pada tiap-tiap roda kendaraan, dimana sudut slip merupakan sudut yang terjadi antara sumbu longitudinal roda terhadap arah pergerakan nyata roda saat berbelok.

Perilaku Ackermann dapat ditemui pada kendaraan yang sedang berbelok pada kecepatan sangat rendah atau pada kendaraan yang berbelok dengan radius belok yang sangat besar, dimana sudut slip yang terjadi pada tiap-tiap roda sangat minim atau bahkan nihil. Perilaku berbelok netral merupakan perilaku yang umum dijumpai dalam kondisi sehari-hari dimana akan dijumpai sudut slip pada tiap-tiap roda akibat adanya gaya sentrifugal yang terjadi saat kendaraan berbelok. Pada perilaku belok netral, sudut slip yang dibentuk oleh roda depan maupun belakang adalah sama besar. Apabila sebuah kendaraan memiliki sudut slip yang berbeda besarnya pada roda depan maupun belakang, maka perilaku berbeloknya dapat berupa understeer atau oversteer.

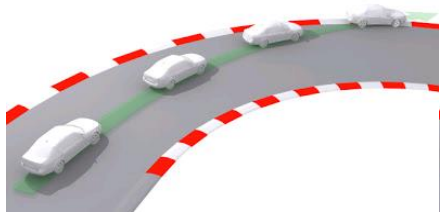

(a)

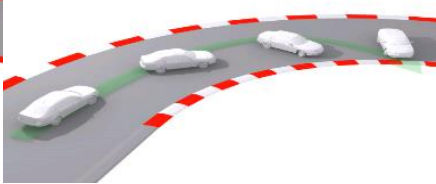

(b)
Gambar 3. Perilaku berbelok (a) understeer dan (b) oversteer [3]

Gambar 1(a) menunjukkan perilaku understeer dimana kendaraan berbelok kurang dari input setir yang diberikan pengemudi, sehingga kendaraan cenderung bergerak melebar keluar dari trayektori belok yang seharusnya. Hal ini disebabkan apabila kendaraan mengalami sudut slip roda depan lebih besar dari pada roda belakang. Pada kasus sebaliknya, terjadi perilaku oversteer yang ditunjukkan oleh gambar 1(b) dimana kendaraan berbelok melebihi imput setir yang diberikan pengemudi, sehingga kendaraan cenderung bergerak menyempit dari trayektori belok yang seharusnya. Hal ini disebabkan apabila kendaraan mengalami sudut slip roda belakang lebih besar daripada roda depan.

Pada tingkat ekstrem, kondisi understeer dapat menyebabkan kendaraan gagal dibelokkan dan pada kondisi oversteer menyebabkan kendaraan terpuntir dan kehilangan kendali, sehingga kedua perilaku berbelok tersebut harus dapat diminimalisir.

\section{Pengaruh Kondisi Permukaan Jalan Terhadap Perilaku Belok Kendaraan}

Kondisi permukaan jalan memiliki peran yang penting terhadap perilaku arah kendaraan terutama dalam membantu menahan gaya-gaya longitudinal dan lateral yang terjadi pada kendaraan. Permukaan jalan dengan koefisien gesek yang baik akan membantu kestabilan saat berkendara. Berikut ini merupakan hasil studi dari J. J. Taborek [4] mengenai koefisien adhesi rata-rata antara ban dan jalan serta koefisien hambatan rolling untuk beberapa jenis permukaan jalan yang ditunjukkan oleh tabel 1 dan 2.

Koefisien adhesi dan koefisien hambat rolling berpengaruh langsung pada perilaku belok dan karakteristik handling pada kendaraam dimana koefisien adhesi berpengaruh terhadap gaya-gaya longitudinal pada roda kendaraan dan koefisien 
hambat rolling berpengaruh kepada gaya hambat rolling yang harus dilawan oleh sistem pembangkit daya dan penggerak kendaraan.

Tabel 1.

Koefisien adhesi ban pada bermacam-macam jenis permukaan jalan [4]

\begin{tabular}{lcc}
\hline \hline Permukaan Jalan & $\begin{array}{c}\text { Koefisien Adhesi } \\
\text { Tertinggi }\left(\mu_{\mathrm{p}}\right)\end{array}$ & $\begin{array}{c}\text { Koefisien Adhesi Roda } \\
\text { Lock }\left(\mu_{\mathrm{s}}\right)\end{array}$ \\
\hline $\begin{array}{l}\text { Aspal dan beton } \\
\text { (kering) }\end{array}$ & $0,8-0,9$ & 0,75 \\
Aspal (basah) & $0,5-0,7$ & \\
Beton (basah) & 0,8 & $0,55-0,6$ \\
Gravel & 0,6 & 0,7 \\
Jalan tanah & 0,68 & 0,55 \\
(kering) & & 0,65 \\
Jalan tanah (basah) & 0,55 & \\
Salju & 0,2 & $0,4-0,5$ \\
Es & 0,2 & 0,15 \\
\hline \hline
\end{tabular}

Tabel 2.

Nilai rata-rata koefisien hambatan rolling untuk berbagai jenis ban kendaraan dan berbagi kondisi permukaan jalan [4]

\begin{tabular}{lccc}
\hline \hline \multirow{2}{*}{ Jenis Kendaraan } & \multicolumn{3}{c}{ Permukaan Jalan } \\
& Beton & Keras/Aspal & Pasir \\
\hline Kendaraan penumpang & 0,015 & 0,08 & 0,3 \\
Truk & 0,012 & 0,06 & 0,25 \\
Traktor & 0,020 & 0,04 & 0,2 \\
\hline \hline
\end{tabular}

\section{Analisis Slip}

Besarnya sudut slip yang terjadi pada tiap-tiap roda kendaraan dapat dirumuskan dengan persamaan berikut [5].

$$
\alpha_{\mathrm{i}}=\frac{\mathrm{C}_{\mathrm{rp}}}{\mathrm{C}_{\mathrm{rs}}} \cdot \frac{\mathrm{C}_{\mathrm{rx}}}{\mathrm{C}_{\mathrm{ro}}}\left[0,087935\left(\mathrm{~F}_{\mathrm{y} \alpha_{\mathrm{i}}}\right)^{0,79008}-0,005277\left(\mathrm{~F}_{\mathrm{z}_{\mathrm{i}}}\right)\right]
$$

Dimana $\mathrm{F}_{\mathrm{y}}$ merupakan gaya longitudinal dan $\mathrm{F}_{\mathrm{z}}$ merupakan gaya vertikal yang terjadi pada tiap-tiap roda. Perumusan untuk $\mathrm{C}_{\mathrm{rp}}, \mathrm{C}_{\mathrm{rs}}, \mathrm{C}_{\mathrm{rx}}$, dan $\mathrm{C}_{\mathrm{ro}}$ dapat dituliskan sebagai berikut.

$$
\begin{aligned}
& \mathrm{C}_{r p}=3,35+5,30(\mathrm{P})-0,0916(\mathrm{P})^{2} \\
& \mathrm{C}_{r s}=3,35+5,30\left(\mathrm{P}_{\mathrm{s}}\right)-0,0916\left(\mathrm{P}_{\mathrm{s}}\right)^{2} \\
& \mathrm{C}_{r x}=\left[\frac{\mathrm{F}_{\mathrm{y} \alpha \mathrm{i}}+0,107927\left(\mathrm{~F}_{\mathrm{x}}\right)}{161,1398}\right]^{\frac{1}{0,474998}} \\
& \mathrm{C}_{r o}=\left[\frac{\mathrm{F}_{\mathrm{y} \alpha \mathrm{i}}}{161,1398}\right]^{\frac{1}{0,474998}}
\end{aligned}
$$

Hubungan antara $\alpha_{\mathrm{f}}^{\circ}$ dan $\alpha_{\mathrm{r}}^{\circ}$ menentukan perilaku kendaraan saat berbelok, dimana apabila:

a. $\quad \alpha_{f}>\alpha_{r}$, maka kendaraan akan mengalami understeer

b. $\alpha_{f}=\alpha_{r}$, maka kendaraan mengalami perilaku netral

c. $\alpha_{f}<\alpha_{r}$, maka kendaraan akan mengalami oversteer

\section{E. Analisis Indeks Understeer ( $\left.K_{U S}\right)$}

Indeks understeer $\left(\mathrm{K}_{\mathrm{US}}\right)$ merupakan salah satu tolok ukur yang dapat digunakan untuk menentukan perilaku belok kendaraan dengan mempertimbangkan sudut slip yang terjadi pada tiap roda dan gaya sentrifugal. Nilai $K_{U S}$ dapat dirumuskan sebagai berikut.

$$
\mathrm{K}_{\mathrm{US}}=\frac{\mathrm{g} \cdot \mathrm{R}}{\mathrm{V}^{2}}\left(\alpha_{\mathrm{f}}^{\circ}-\alpha_{\mathrm{r}}^{\circ}\right)
$$

Apabila $\mathrm{K}_{\mathrm{US}}$ bernilai positif, maka kendaraan akan berperilaku understeer. Sebaliknya, apabila $\mathrm{K}_{\mathrm{US}}$ bernilai negatif, maka kendaraan berperilaku oversteer. Kendaraan akan berperilaku netral apabila $\mathrm{K}_{\mathrm{US}}$ bernilai 0 .

\section{F. Analisis Skid}

Skid atau bergesernya roda ke arah lateral terjadi apabila gaya-gaya ke arah lateral, tidak mampu lagi ditahan oleh gaya gesek yang terjadi antara permukaan roda dan permukaan jalan. Sehingga untuk menghindari terjadinya skid, gaya gesek antara roda dan permukaan jalan harus lebih dari atau sama dengan gaya-gaya lateral yang terjadi. Dengan begitu dapat dirumuskan suatu tingkat kecepatan yang menjadi batas maksimum sebelum terjadinya skid pada roda depan dan belakang, yang masingmasing disebut dengan $\mathrm{V}_{\text {sf }}$ dan $\mathrm{V}_{\mathrm{sr}}$, yang dirumuskan sebagai berikut.

$$
\begin{aligned}
& \mathrm{V}_{\mathrm{sf}}=\sqrt{\frac{\mu \cdot \mathrm{F}_{\mathrm{f}_{\text {ras }}} \cdot \mathrm{W}}{\left(\frac{\mathrm{F}_{\text {ras }} \cdot \mathrm{W} \cdot \operatorname{Cos} \beta}{\mathrm{g} \cdot \mathrm{R}}\right)-\mathrm{A} \cdot \mathrm{B}}} \\
& \mathrm{V}_{\mathrm{sr}}=\sqrt{\frac{\mu \cdot \mathrm{F}_{\mathrm{r}_{\text {ras }}} \cdot \mathrm{W}}{\left(\frac{\mathrm{F}_{\mathrm{r}_{\text {ras }}} \cdot \mathrm{W} \cdot \mathrm{Cos} \beta}{\mathrm{g} \cdot \mathrm{R}}\right)+\mathrm{A} \cdot \mathrm{B}}}
\end{aligned}
$$

Dengan,

$$
\begin{aligned}
& A=\mu\left(\frac{\mathrm{W} \cdot \sin \beta}{\mathrm{g} \cdot \mathrm{R}}-\frac{\rho \cdot \mathrm{C}_{\mathrm{D}} \cdot \mathrm{A}_{\mathrm{f}}}{2}\right) \\
& B=\left(\mathrm{r}_{\mathrm{c}}+\mathrm{h}_{\mathrm{gf}}+\left(\frac{\mathrm{W} \cdot \mathrm{r}_{\mathrm{c}}{ }^{2}}{2 \mathrm{~K}_{\text {eqf }} \cdot \mathrm{Lf}_{\mathrm{f}}{ }^{2}+2 \mathrm{~K}_{\text {eqm }} \mathrm{L}_{\mathrm{m}}{ }^{2}+2 \mathrm{~K}_{\mathrm{eqr}} \cdot \mathrm{Lr}_{\mathrm{r}}{ }^{2}-\mathrm{W} \cdot \mathrm{r}_{\mathrm{c}}}\right)\right)
\end{aligned}
$$

Apabila $\mathrm{V}_{\text {sf }}$ lebih kecil dari $\mathrm{V}_{\mathrm{sr}}$, hal ini menunjukkan kecepatan maksimum sebelum terjadi skid pada roda depan lebih kecil dari roda belakang, sehingga roda depan akan lebih dahulu mengalami skid. Hal ini menandakan kendaraan akan berperilaku understeer. Apabila berlaku sebaliknya, maka kendaraan akan berperilaku oversteer.

\section{G. Analisis Guling}

Sebuah kendaraan akan mengalami kondisi terguling (roll) apabila salah satu roda pada sisi kiri atau kanan kendaraan terangkat. Roda yang terangkat menandakan gaya vertikal ke arah bawah (positif) sudah tidak ada lagi (dapat bernilai nol maupun negatif). Roda yang terangkat akan mempengaruhi perilaku belok kendaraan, dimana hal tersebut dapat dianalisis dengan mengetahui kecepatan maksimum (kritis) sebelum terjadinya roda terangkat pada bagian depan maupun belakang kendaraan, yang masing-masing disebut $\mathrm{V}_{\mathrm{gf}}$ dan $\mathrm{V}_{\mathrm{gr}}$. Perumusan untuk $\mathrm{V}_{\mathrm{gf}}$ dan $\mathrm{V}_{\mathrm{gr}}$ dapat dirumuskan sebagai berikut.

$$
\begin{aligned}
& \mathrm{V}_{\mathrm{gf}}=\sqrt{\frac{\mathrm{F}_{\text {ras }} \cdot \mathrm{W} \cdot \mathrm{t}_{\mathrm{f}}}{C-\mathrm{D}}} \\
& \mathrm{V}_{\mathrm{gr}}=\sqrt{\frac{\mathrm{F}_{\mathrm{r}_{r a s} \cdot \mathrm{W} \cdot \mathrm{t}_{\mathrm{r}}}}{C+D}}
\end{aligned}
$$

Dengan,

$$
\begin{aligned}
& C=\left(\frac{2 \mathrm{~W} \cdot \cos \beta}{\mathrm{g} \cdot \mathrm{R}}\right)\left(\mathrm{F}_{\mathrm{f}_{\text {ras }}} \cdot \mathrm{h}_{\mathrm{gf}}+\mathrm{F}_{\mathrm{f}_{\text {ras }}} \cdot \mathrm{r}_{\mathrm{c}}+\frac{\mathrm{W} \cdot \mathrm{r}_{\mathrm{c}}{ }^{2} \frac{\mathrm{F}_{\text {fras }}}{F_{r a s}}}{\mathrm{~K}_{\text {eqf }} \cdot \frac{\mathrm{b}_{\mathrm{f}}{ }^{2}}{2}-\left(\frac{F_{f}}{F}\right)_{\text {ras }} \cdot \mathrm{W} \cdot \mathrm{r}_{\mathrm{c}}}\right) \\
& D=\mathrm{t}_{\mathrm{f}}\left(\frac{\mathrm{W} \cdot \sin \beta}{\mathrm{g} \cdot \mathrm{R}}-\frac{\rho \cdot \mathrm{C}_{\mathrm{D}} \cdot \mathrm{A}_{\mathrm{f}}}{2}\right) \cdot \mathrm{B}
\end{aligned}
$$


Apabila $\mathrm{V}_{\mathrm{gf}}$ lebih kecil dari $\mathrm{V}_{\mathrm{gr}}$, hal ini menunjukkan kecepatan kritis sebelum roda depan terangkat lebih kecil dari roda belakang, sehingga roda depan akan lebih dahulu mengalami salah satu roda terangkat. Hal ini menandakan kendaraan akan berperilaku understeer. Apabila berlaku sebaliknya, maka kendaraan akan berperilaku oversteer.

\section{HASIL DAN PEMBAHASAN}

\section{A. Spesifikasi Teknis Kendaraan}

Spesifikasi teknis dari Panser Anoa 6X6 APC yang diteliti ditunjukkan pada Tabel 1 berikut.

Tabel 3.

Spesifikasi Teknis Panser Anoa 6X6 APC

\begin{tabular}{|c|c|}
\hline \multicolumn{2}{|l|}{ Dimensi } \\
\hline Panjang keseluruhan & $6000 \mathrm{~mm}$ \\
\hline Lebar keseluruhan & $2500 \mathrm{~mm}$ \\
\hline Jarak total sumbu roda (L) & $3020 \mathrm{~mm}$ \\
\hline Jarak antar sumbu ke sumbu berdekatan & $1510 \mathrm{~mm}$ \\
\hline Lebar pijak roda (tr) & $2035 \mathrm{~mm}$ \\
\hline Bentang titik kerja suspensi (b) & $1080 \mathrm{~mm}$ \\
\hline Radius belok minimum & $<10000 \mathrm{~mm}$ \\
\hline Ground clearance & $400 \mathrm{~mm}$ \\
\hline \multicolumn{2}{|c|}{ Massa Kendaraan } \\
\hline Massa total (M) & $12850 \mathrm{Kg}$ \\
\hline \multicolumn{2}{|l|}{ Suspensi } \\
\hline Depan & $\begin{array}{l}\text { Independent Torsion } \\
\text { Bar }\end{array}$ \\
\hline $\begin{array}{l}\text { Kekakuan pegas suspensi depan dan } \\
\text { tengah }\left(\mathrm{K}_{\mathrm{f}}, \mathrm{K}_{\mathrm{m}}\right)\end{array}$ & 290 N/mm eqv. \\
\hline Kekakuan pegas suspensi belakang $\left(\mathrm{K}_{\mathrm{r}}\right)$ & $285 \mathrm{~N} / \mathrm{mm}$ eqv. \\
\hline \multicolumn{2}{|l|}{ Aerodinamika } \\
\hline Luas frontal kendaraan $\left(A_{f}\right)$ & $3,1 \mathrm{~m}^{2}$ \\
\hline Massa jenis angin $(\rho)$ & $1,23 \mathrm{Kg} / \mathrm{m}^{3}$ \\
\hline Koefisien drag $\left(\mathrm{C}_{\mathrm{d}}\right)$ & 0,55 \\
\hline \multicolumn{2}{|l|}{ Ban } \\
\hline Jenis ban & Radial \\
\hline Diameter rim & 20 in \\
\hline Lebar ban & $400 \mathrm{~mm}$ \\
\hline
\end{tabular}

B. Analisis Skid dan $K_{U S}$

Setelah dilakukan perhitungan terhadap sudut slip yang terjadi pada tiap-tiap roda, didapatkan nilai yang ditampilkan pada grafik di gambar 2 berikut.

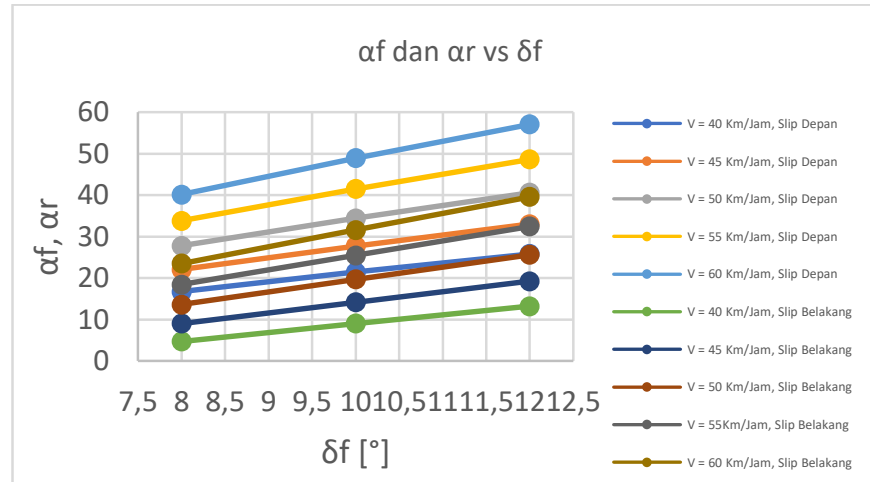

Gambar 4. Grafik Perbandingan antara Sudut Slip Depan dan Belakang terhadap Sudut Belok Kendaraan
Dari grafik tersebut dapat dilihat bahwa nilai sudut slip pada roda depan kendaraan selalu lebih besar daripada roda belakang. Hal ini menunjukkan kendaraan memiliki kecenderungan untuk understeer pada tiap rentang kecepatan dan sudut belok yang digunakan pada penelitian.

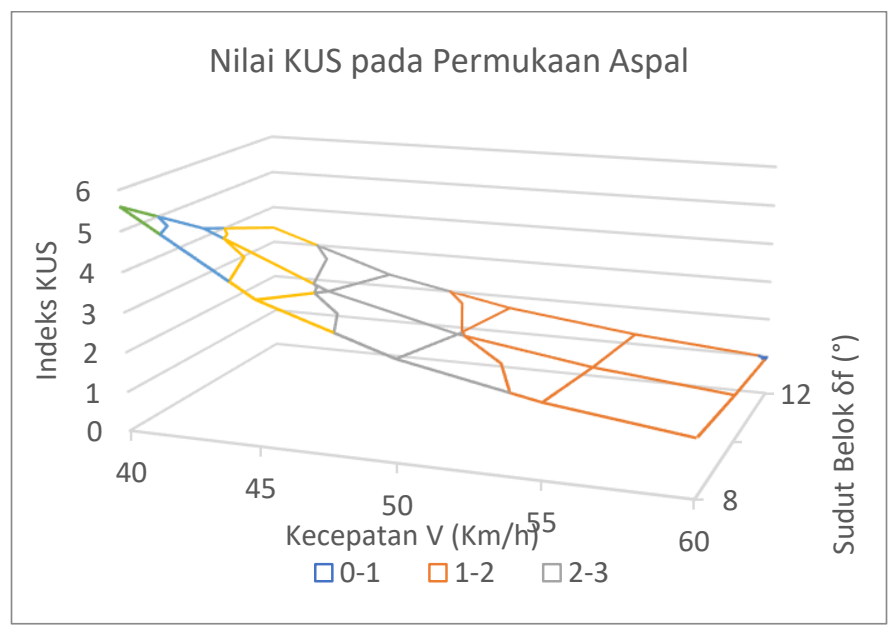

Gambar 5. Grafik Nilai $\mathrm{K}_{\mathrm{US}}$ pada Permukaan Aspal

Terlihat pada gambar 3 dan 4 bahwa nilai $\mathrm{K}_{U S}$ selalu bernilai positif di berbagai rentang kecepatan, sudut belok yang digunakan, maupun jenis medan yang dilalui kendaraan. Hal ini menunjukkan bahwa Panser Anoa memiliki kecenderungan untuk understeer.

Namun, seiring kecepatan bertambah dan sudut belok yang semakin besar, hal ini akan berpengaruh kepada semakin besarnya nilai gaya sentrifugal yang akan menyebabkan kendaraan akan mulai mendekati perilaku oversteer, terlihat dari nilai $\mathrm{K}_{\mathrm{US}}$ yang semakin menurun seiring kecepatan dan sudut belok meningkat.

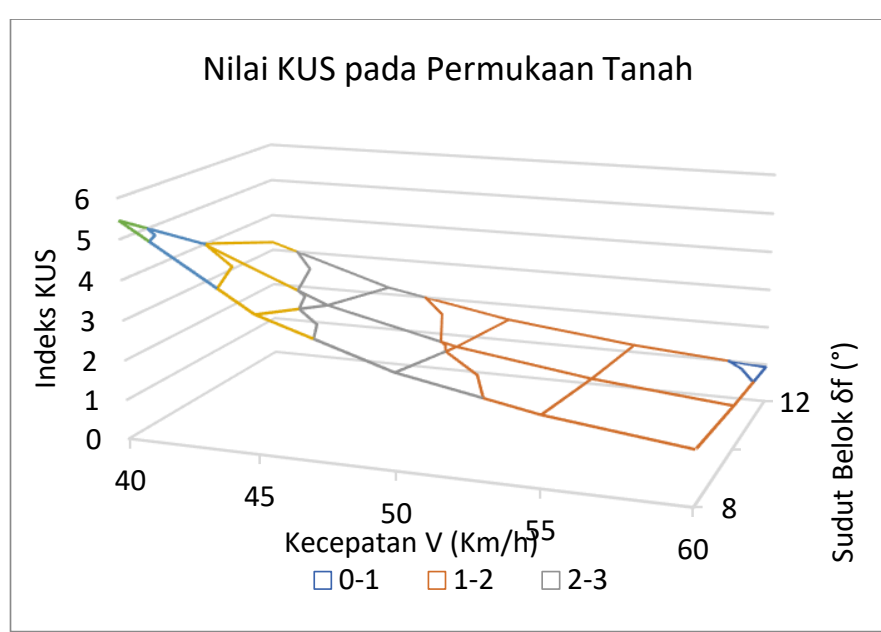

Gambar 6. Grafik Nilai $K_{\text {Us }}$ pada Permukaan Tanah

\section{Analisis Skid}

Parameter $\mathrm{V}_{\text {sf }}$ dan $\mathrm{V}_{\text {sr }}$ yang dijadikan acuan dalam analisis skid akan disajikan dalam gambar 5 dan 6 berikut. 


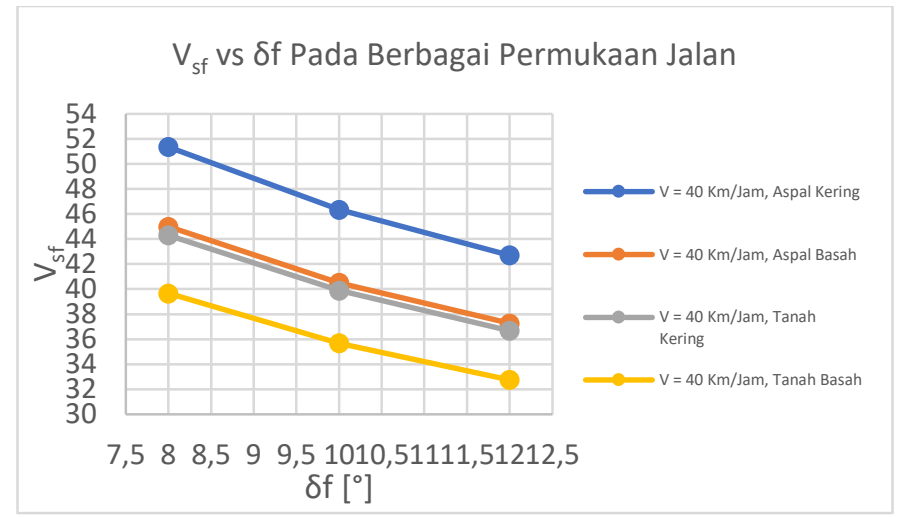

Gambar 7. Grafik $V_{\text {sf }}$ Terhadap Sudut Belok

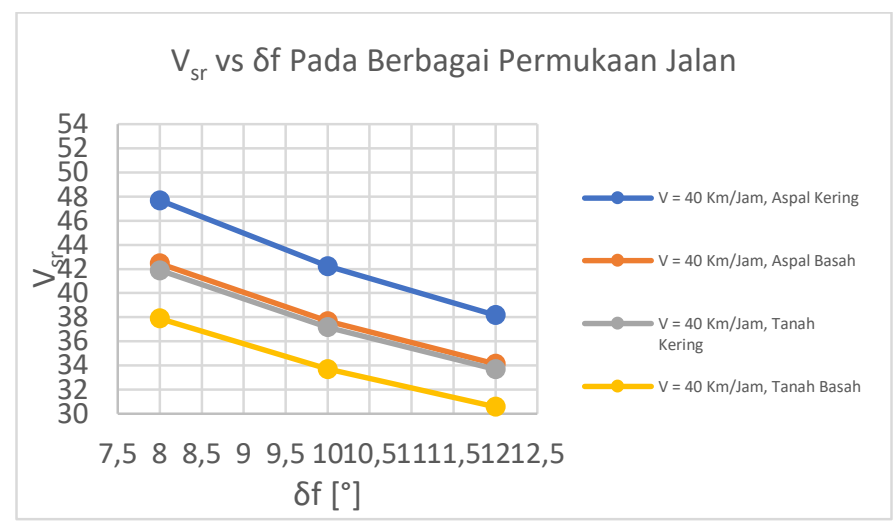

Gambar 8. Grafik $\mathrm{V}_{\text {sr }}$ Terhadap Sudut Belok

Terlihat bahwa pada tiap sudut belok maupun jenis permukaan jalan yang dilalui, nilai $\mathrm{V}_{\text {sf }}$ Panser Anoa 6X6 APC selalu lebih besar dari nilai $\mathrm{V}_{\text {sr }}$ yang terjadi, namun perbedaan yang ada tidak terlalu signifikan. Hal ini menunjukkan bahwa berdasarkan analisis skid, kendaraan akan cenderung memiliki karakter oversteer, namun tidak terlalu signifikan. Terlihat juga dari tiap-tiap jenis permukaan yang diteliti, masing-masing trendline data mengalami penurunan seiring menurunnya koefisien gesek yang terjadi antara ban dan masing-masing permukaan jalan.

\section{Analisis Guling}

Parameter $\mathrm{V}_{\mathrm{gf}}$ dan $\mathrm{V}_{\mathrm{gr}}$ yang dijadikan acuan dalam analisis skid akan disajikan dalam gambar 7 berikut.

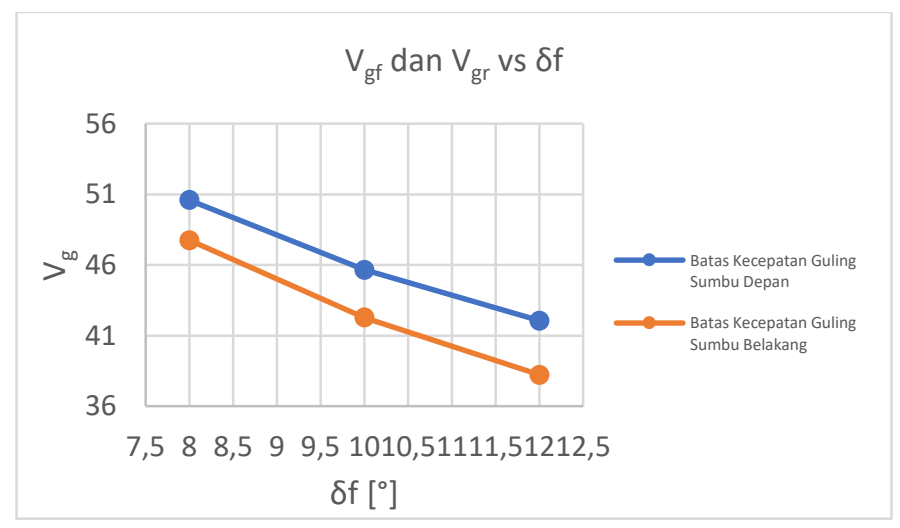

Gambar 9. Grafik $\mathrm{V}_{\mathrm{gf}}$ dan $\mathrm{V}_{\mathrm{gr}}$ Terhadap Sudut Belok
Terlihat pada grafik di gambar 7 bahwa nilai $\mathrm{V}_{\mathrm{gf}}$ selalu lebih besar dari $\mathrm{V}_{\mathrm{gr}}$ pada berbagai rentang kecepatan, sudut belok, dan jenis permukaan yang diteliti. Hal ini menandakan bahwa Panser Anoa 6X6 APC memiliki kecenderungan karakter oversteer, namun tidak signifikan.

\section{KESIMPULAN}

Dapat disimpulkan dari hasil yang didapatkan bahwa secara analisis slip dan $\mathrm{K}_{\mathrm{US}}$, Panser Anoa 6X6 APC memiliki karakter understeer karena sudut slip depannya yang lebih besar dari sudut slip belakang. Sementara berdasarkan analisis skid dan guling, kendaraan cenderung bersifat sedikit oversteer karena kecepatan kritis skid maupun gulingnya selalu lebih besar pada roda belakang. Hal yang demikian tidak bertentangan, karena kondisi oversteer hanya akan dialami pada kecepatan tinggi dan karakter understeer dari kendaraan sendiri akan menurun seiring meningkatnya kecepatan dan sudut belok kendaraan.

\section{DAFTAR PUSTAKA}

[1] J. H. K. Huh, J. Kim, "Handling and Driving Characteristics for SixWheeled Vehicle," Hanyang University Korea, 1999.

[2] D. Andriansyah, "Analisis Pengaruh Parameter Operasional dan Penggunaan Stabilizer terhadap Perilaku Arah Belok Mobil Toyota Fortuner 4.0 V6 SR (AT 4X4)," ITS, 2016.

[3] U. R. Malaysia, "What Is Vehicle Handling." [Online]. Available: http://ultraracing.my/v1/?page_id=2267.

[4] J. J. Taborek, Mechanics of Vehicle. Cleveland: Penton Pubilshing Co, 1957.

[5] dan B. S. Sutantra, I Nyoman, Teknologi Otomotif, Edisi Kedua. Surabaya: Guna Widya, 2010. 